\title{
Assessment of liver stiffness with transient elastography by using $S$ and $M$ probes in healthy children
}

\author{
Giovanna Ferraioli • Raffaella Lissandrin • \\ Mabel Zicchetti • Carlo Filice
}

Received: 18 May 2012 / Accepted: 11 June 2012 / Published online: 23 June 2012

(C) Springer-Verlag 2012

We read with great interest the article by Engelmann et al. [2] in the February 2012 issue of EJP and would like to raise an important issue in relation to their work. In their study, the authors investigated the feasibility of transient elastography (TE) in healthy children to define normal values of liver stiffness. Examinations were performed by using two types of probes ( $\mathrm{S}$ or $\mathrm{M}$ ) depending on thorax circumference and according to the manufacturer recommendations. By using the appropriate probe, normal liver stiffness values were 4.40, 4.73, and $5.1 \mathrm{kPa}$, respectively, in three age groups-namely $0-5,6-11$, and $12-18$ years. Eighty percent of measurements were performed with the S probe and $20 \%$ with the $\mathrm{M}$ probe.

Unfortunately, the utilization of different probes (S or M) introduces a severe bias that limits the results of the study. Indeed, the values obtained with different probes are not comparable due to technical aspects, such as focal length, vibration amplitude, and depth of measurement [5]. In adults, it has been demonstrated that TE results obtained by using $\mathrm{M}$ and XL probes are systematically different because of the different region of interest [1, 3, 5]. Myers et al. [5] have found that, in patients who were studied with both probes, the values obtained with XL probe were 1-2 $\mathrm{kPa}$ lower than that obtained

G. Ferraioli $(\bowtie) \cdot$ R. Lissandrin $\cdot$ M. Zicchetti $\cdot$ C. Filice Ultrasound Unit, Infectious Diseases Department, Fondazione IRCCS Policlinico San Matteo, University of Pavia,

Via Taramelli 5,

27100, Pavia, Italy

e-mail: giovanna.ferraioli@unipv.it with the $\mathrm{M}$ probe. It can be inferred that similar differences could also be expected between the $\mathrm{S}$ and $\mathrm{M}$ probes, and this aspect should be taken into account and thoroughly investigated. On the other hand, in a recent study, in which the results of TE measurements obtained with an XL probe were compared to that of liver biopsy, it was found that there was an overestimation of liver fibrosis with the XL probe [4].

\section{References}

1. de Ledinghen V, Vergniol J, Foucher J, El-Hajbi F, Merrouche W, Rigalleau V (2010) Feasibility of liver transient elastography with FibroScan using a new probe for obese patients. Liver Int 30:10431048

2. Engelmann G, Gebhardt C, Wenning D, Wuhl E, Hoffmann G, Selmi B, Grulich-Henn J, Schenk JP, Teufel U (2012) Feasibility study and control values of transient elastography in healthy children. Eur J Pediatr 171:353-360

3. Friedrich-Rust M, Hadji-Hosseini H, Kriener S, Herrmann E, Sircar I, Kau A, Zeuzem S, Bojunga J (2010) Transient elastography with a new probe for obese patients for non-invasive staging of nonalcoholic steatohepatitis. Eur Radiol 20:2390-2396

4. Myers R, Pomier-Layrargues G, Kirsch R, Pollett A, Beaton M, Levstik M, Duarte-Rojo A, Wong D, Crotty P, Elkashab M (2011) Discordance in fibrosis staging between liver biopsy and transient elastography using the fibroscan XL probe. J Hepatol. doi:10.1016/ j.hep. 2011.10.007

5. Myers R, Pomier-Layrargues G, Kirsch R, Pollett A, Duarte-Rojo A, Wong D, Beaton M, Levstik M, Crotty P, Elkashab M (2012) Feasibility and diagnostic performance of the FibroScan XL probe for liver stiffness measurement in overweight and obese patients. Hepatology 55:199-208 